- Haussler MR. Vitamin D; mode of action and biomedical applications. Nutr Rev $1974 ; 32: 257-66$.

- Albright F, Ellsworth R. Studies on the physiology of the parathyroid glands. Calcium and phosphorus studies on a case of idiopathic hypoparathyroidism. F Clin Invest 1929;7:183-201.

7 Talmage RV, Kraintz FW, Buchanan GD. Effect of parathyroid extract and phosphate salts on renal calcium and phosphate excretion after parathyroidectomy. Proc Soc Exp Biol 1954;87:263-7.

${ }^{8}$ Haussler MR, McCain TA. Basic and clinical concepts related to vitamin D metabolism and action. N Engl f Med 1977;297:974-83.

- Garabedian M, Tanaka Y, Holic MF, Deluca HF. Response of intestinal calcium transport and bone calcium mobilization to 1,25 dihydroxy vitamin D3 in thyroparathyroidectomized rats. Endocrinology 1974;94 1022-7.

${ }^{10}$ Avioli LV. The therapeutic approach to hypoparathyroidism. Am $\mathcal{F}$ Med $1974 ; 57: 34-42$.

1 Russell RGG, Walton RJ, Smith R, et al. 1,25 Dihydroxycholecalciferol and $1 \propto$ hydroxycholecalciferol in hypoparathyroidism. Lancet 1974 ;ii: 14-7.

12 Davies M, Taylor CM, Hill LF, Stanbury SW. 1,25 Dihydroxycholecalciferol in hypoparathyroidism. Lancet 1977 ; i :55-9.

${ }^{13}$ Parfitt AM. Vitamin D treatment in hypoparathyroidism. Lancet 1970;ii 614-5.

14 Ribvich ML, Deluca HF. Intestinal calcium transport: parathyroid hormone and adaptation to dietary calcium. Arch Biochem Biophys $1976 ; 175: 256-61$

15 Peacock M, Robertson WG. Relation between serum and urinary calcium with particular reference to parathyroid activity. Lancet 1969;i:384-6.
16 Anonymous. Correcting the calcium [Editorial], Br Med F 1977; :598.

7 Nordin BEC, Horsman A, Aaron J. Diagnostic procedures. In: Nordin BEC, ed. Calcium phosphate and magnesium metabolism. Edinburgh: C Churchill Livingstone, 1976:472-5.

1* Nagent de Deuxchaines D, Krane SM. In: Avioli LV, Krane SM, eds. Hypoparathyroidism in metabolic bone disease. Vol 2. New York: Academic Press, 1978:405-15.

19 Kanis JA, Russell RGG. Rate of reversal of hypercalcaemia and hyper- $\mathbb{D}$ calciuria induced by vitamin $\mathrm{D}$ and its 1 -hydroxylated derivatives. Br Med F 1977; i:78-81.

20 Breslau NA, Pak CYC. Hypoparathyroidism. Metabolism 1979;28:126176.

21 Nordin BEC. Plasmacalcium and plasma magnesium homeostasis. In: Nordin BEC, ed. Calcium phosphate and magnesium metabolism. Edinburgh: Churchill Livingstone, 1976:186-208.

22 Reeve J, Hesp R, Veall N. Effects of therapy on rate of absorption of calcium from gut in disorders of calcium homeostasis. $\mathrm{Br}$ Med $\mathcal{f} 1974$;iii: 310-3.

${ }^{23}$ Puschett JB, Moranz J, Kurnick W. Evidence for a direct action of ๗ֶ cholecalciferol and 25 hydroxycholecalciferol on the renal transport of $\vec{\nabla}$ phosphate, sodium and calcium. $\mathcal{F}$ Clin Invest 1972;51:373-85.

24 Puschett JB, Fernandex PC, Boyle IT, Gray RW, Omdahl JL, Deluca HF. The acute renal tubular effects of 1,25 dihydroxycholecalciferol. Proc $\sigma$ Soc Exp Biol Med 1972;141:379-84.

25 Borle AB. Membrane transfer of calcium. Clin Orthop 1967;52:267-91.

(Accepted 11 May 1983)

\title{
Presence of human papillomavirus DNA sequences in cervical intraepithelial neoplasia
}

\author{
D J MCCANCE, P G WALKER, J L DYSON, D V COLEMAN, A SINGER
}

\begin{abstract}
Twenty two patients referred to a district colposcopy clinic because of an abnormal cervical cytology report or a suspicious cervix and found to have a cervical epithelial abnormality were studied. The techniques of cytology, histology, immunohistochemistry, and DNADNA hybridisation were used to detect infection by human papillomavirus. Using an indirect immunoalkaline phosphatase technique human papillomavirus antigen was found in biopsy specimens from six of the 22 patients and DNA of papillomavirus type 6 in biopsy specimens from 13 of these women, including four out of six whose histological diagnosis was cervical intraepithelial neoplasia grade 3 . In eight cases where cytological, colposcopical, and histological investigations all indicated the presence of wart virus infection, papillomavirus type 6 DNA was found in seven.
\end{abstract}

Papillomavirus type 6 DNA was found in more than Department of Microbiology, Guy's Hospital Medical School,
London SE1 9RT

D J MCCANCE, PHD, lecturer

Departments of Gynaecology and Pathology, Royal Northern Hospital, Holloway, London N7

P G WALKER, MRCOG, research fellow

J L DYSON, MD, FRCPATH, consultant

A SINGER, DPHIL, FRCOG, consultant

Department of Pathology, St Mary's Hospital Medical School, London W2

D V COLEMAN, MD, MRCPATH, senior lecturer

Correspondence and requests for reprints to: Dr D J McCance. half of the proved cases of cervical intraepithelial neoplasia. The presence of this viral DNA in women with no cervical abnormality is to be studied.

\section{Introduction}

Until recently infection of the uterine cervix by human papillomavirus was thought to be rare. Reviewing the published $\overrightarrow{0}$ reports in 1952 Marsh described 23 cases of papillomatous disease of the cervix, of which only 10 were considered to be condylomata acuminata. ${ }^{1}$ In 1954 Raftery and Payne suggested that condyloma of the cervix might not be so uncommon and 3 they found histological evidence of condylomata acuminata in 19 of 587 biopsy specimens from the cervix uteri seen in their department in the years 1949-54. ${ }^{2}$ Although Oriel in 1971 described nine cases of exophytic cervical condylomata in $141 \stackrel{5}{5}$ women presenting with genital warts, ${ }^{3}$ the condition was still $\mathcal{N}$ thought to be relatively uncommon until two groups working $\rightarrow$ independently in Canada and Finland described cytological changes in cervical smears suggestive of wart virus infection. ${ }^{45} \mathrm{~N}$ Meisels found evidence of wart virus infection in over $1 \%$ of N smears from the routinely screened population and suggested $\omega$ that $70 \%$ of cases previously diagnosed as mild dysplasia might in fact be reassigned to a wart virus infection category. ${ }^{6}$ Describ- $\stackrel{\circ}{=}$ ing histological changes consistent with a diagnosis of wart $\stackrel{\oplus}{\rightarrow}$ virus infection, Reid found evidence of human papillomavirus infection in over $90 \%$ of biopsy specimens from patients with ${ }_{0}^{\circ}$ cervical intraepithelial neoplasia and invasive cancer. ${ }^{7}$ The $\mathbb{D}$ apparent increase in the prevalence of cervical wart virus $\frac{O}{\mathbb{D}}$ infection is explained by detection of a previously unrecognised $\varrho$ "flat wart" lesion, not visible with the naked eye but seen with the increased magnification of colposcopy." On colposcopy, 8 morphological changes other than exophytic condylomata acuminata have been described as evidence of human papil-흘 
lomavirus infection. ${ }^{8}$ Immunohistochemical techniques have been developed for identifying human papillomavirus antigen in cervical biopsy specimens, " snd this antigen has been found in $20 \cdot 1^{\prime \prime}$ " of 139 biopsy specimens from patients presenting with abnormal smears. ${ }^{9}$ In cervical warts, however, as in condylomata acuminata of the vulva there is reduced expression of viral antigen," 12 and human papillomavirus infection may be more common than this among patients with cervical epithelial abnormalities.

With the development of more sensitive techniques of detecting the presence of viral DNA, such as DNA-DNA hybridisation, detection of small amounts of viral genomes in human tissues is possible. ${ }^{1 ?}$ is Human papillomavirus type 6 is the papillomavirus associated most commonly with vulvar and exophytic cervical condyloma, ${ }^{16}$ and using plasmid cloned human papillomavirus type 6 DNA we have investigated how often this viral could be found in biopsy specimens from patients attending a colposcopy clinic with cervical epithelial abnormalities. From these results we assessed the accuracy of the techniques of colposcopy, cytology, and histology in determining the presence of human papillomavirus infection of the cervix.

\section{Materials and methods}

\section{PATIENTS}

The study group consisted of 22 women attending a district colposcopy clinic, 17 of whom were referred because of an abnormal cytology report. The other five patients had originally attended a clinic for sexually transmitted diseases suffering from vulval warts, but on colposcopy were seen to have a cervical epithelial abnormality. Of these five patients three also had an abnormal cytology report. The group was aged from 18 to 46 years with an average age of 26 years.

\section{COLPOSCOPY AND CYTOLOGY}

Each patient underwent a colposcopy examination at which a cervical smear was taken, fixed, and stained by the Papanicolaou method. Cellular changes (koilocytosis and dyskeratosis ${ }^{4}$ ) that were evidence of wart virus infection and suggestive of cervical intraepithelial neoplasia were sought. ${ }^{17}$ At colposcopy the cervix was washed with $5^{\prime \prime}$, aqueous acetic acid and then examined for acetowhite epithelium within the transformation zone suggestive of a cervical intraepithelial neoplastic lesion, a wart virus lesion, or a mixed lesion. ${ }^{9}$

\section{HISTOLOGY AND IMMUNOHISTOCHEMISTRY}

Two colposcopically directed biopsy specimens were taken from adjacent areas within the same lesion. One of these specimens was fixed in formol sublimate, embedded in paraffin, and sectioned at three levels. Sections for routine histological study were stained with haematoxylin and eosin, and unstained sections used for immunohistochemical study. The second specimen was placed in a tube, snap frozen in liquid nitrogen, and total DNA extracted as described in a previous report. ${ }^{14}$

Histological evidence for wart virus infection was based chiefly on the presence of koilocytotically atypical cells in the upper third of the epithelium. Other changes suggestive of human papillomavirus infection were individual cell keratinisation, the presence of multinucleate cells, hyperkeratosis, and parakeratosis. Cervical intraepithelial neoplastic lesions were classified from grade 1 through to grade 3 (severe dysplasia and carcinoma in situ) by the level of disruption of polarity in the cervical epithelium. ${ }^{17}$

The unstained material was examined for human papillomavirus antigen by an indirect immunoalkaline phosphatase technique ${ }^{9}$ using a broadly cross reactive antiserum, raised by the immunisation of a rabbit with disrupted capsids from virions purified from a pool of plantar warts (donated by Professor K V Shah, Johns Hopkins University, USA). ${ }^{19}$ The presence of papillomavirus antigen was detected by a deep red coloration within the nuclei of affected cells in the upper third of the abnormal epithelium.
DIGESTION OF DNA BY RESTRICTION ENZYMES AND AGAROSE GEL ELECTROPHORESIS

Samples of $10 \mu \mathrm{g}$ of DNA were digested with various restriction enzymes under conditions recommended by the manufacturer (Amersham International, Amersham, Buckinghamshire). The reaction was stopped with edetic acid and DNA fragments precipitated at $-70^{\circ} \mathrm{C}$ with $0 \cdot 1$ volume $5 \mathrm{~mol} / 1$ ammonium acetate and 1 volume of isopropanol. Samples were redissolved in loading buffer $(10 \mathrm{ml}$ trometamol (TRIS) $\mathrm{HCl}(\mathrm{pH} 7.5) ; 1 \mathrm{mmol} / 1$ edetic acid; $50 \%$ sucrose and bromocresol green) and run on a horizontal $0.8 \%$ agarose gel in trometamol-acetate buffer $(40 \mathrm{mmol} / \mathrm{l}$ trometamol $\mathrm{HCl}(\mathrm{pH} 7.5) ; 5 \mathrm{mmol} / 1$ sodium acetate; $1 \mathrm{mmol} / 1$ edetic acid) for $16-18 \mathrm{~h}$ at $1 \mathrm{volt} / \mathrm{cm}$. After electrophoresis the DNA in the gel was denatured in $0.5 \mathrm{~mol} / 1 \mathrm{NaOH}$ and $1 \mathrm{~mol} / 1 \mathrm{NaCl}$ for $1 \mathrm{~h}$ and then neutralised in $1 \mathrm{~mol} / 1$ trometamol, $3 \mathrm{~mol} / 1 \mathrm{NaCl}$ for another hour. The DNA was then transferred from the gel to nitrocellulose filters by the Southern blot technique. ${ }^{20}$

\section{DNA-DNA HYBRIDISATION}

After transfer the nitrocellulose filters were baked at $80^{\circ} \mathrm{C}$ under vacuum and then washed for at least two hours at $68^{\circ} \mathrm{C}$ in 6 times SSC (1 times SSC is $0.15 \mathrm{~mol} / 1$ sodium chloride and $0.015 \mathrm{~mol} / 1$ sodium citrate), $0.2 \%$ ficoll, $0.2 \%$ polyvinylpyrrolidine, and $0.2 \%$ bovine serum albumin. The filters were then transferred to the hybridisation solution, which contained, in addition to the above solution, $400 \mu \mathrm{g} / \mathrm{ml}$ single stranded salmon sperm DNA, $0.1 \%$ sodium dodecyl sulphate (SDS), and the nick translated ${ }^{32} \mathrm{P}$-labelled papillomavirus type $6 \mathrm{DNA}^{21}$; specific activity $1-3 \times 10^{8} \mathrm{cpm} / \mu \mathrm{g}$ DNA). The viral DNA used for nick translation (donated by Dr $\mathbf{L}$ Gissmann, University of Freiberg, West Germany) was recloned in the plasmid pAT 153 for these experiments. After 48 hours the filters were washed three times at room temperature, twice at $68^{\circ} \mathrm{C}$ for one hour each and then three times at room temperature in 0.1 times SSC and $0.1 \%$ SDS and then exposed to Fuji $x$ ray film for 5-7 days.

\section{Results}

Table I gives the diagnostic results of examination by cytology, colposcopy, and histology. In this group of 22 women, 14 had evidence of wart virus infection by cytology, 16 by colposcopy, and 15 by histology. In the eight cases where colposcopy, cytology, and histology all indicated wart virus infection viral antigens were detected in five and papillomavirus type 6 DNA in seven cases. When the techniques were taken separately then the percentage detection of both viral antigens and viral DNA were reduced (table II). In only one of the six cases when antigen was detected was viral DNA not

TABLE I-Results of investigations in patients attending colposcopy clinic with an abnormal cervix

\begin{tabular}{|c|c|c|c|c|c|}
\hline \multirow{2}{*}{$\begin{array}{l}\text { Case } \\
\text { No }\end{array}$} & \multicolumn{3}{|c|}{ Diagnosis } & \multirow{2}{*}{$\begin{array}{l}\text { Human } \\
\text { papilloma- } \\
\text { virus } \\
\text { antigen }\end{array}$} & \multirow{2}{*}{$\begin{array}{l}\text { Human } \\
\text { papilloma- } \\
\text { virus } \\
\text { type } 6 \\
\text { DNA }\end{array}$} \\
\hline & Cytology & Colposcopy & Histology & & \\
\hline $1 *$ & $\mathrm{CIN}+\mathrm{WVI}$ & $C I N+W V I$ & CIN2+ WVI & + & + \\
\hline 2 & CIN + WVI & WVI & CIN $2 / 3+$ WVI & + & + \\
\hline 3 & CIN + WVI & WVI & $\mathrm{CINI}+\mathrm{WVI}$ & + & + \\
\hline 4 & $\mathrm{CIN}+\mathrm{WVI}$ & WVI & CIN1 + WVI & + & - \\
\hline 5 & CIN + WVI & $\mathrm{CIN}+\mathrm{WVI}$ & CIN1 + WVI & + & + \\
\hline 6 & CIN + WVI & CIN + WVI & $\mathrm{CIN} 1 / 2+\mathrm{WVI}$ & - & - \\
\hline $7^{*}$ & CIN + WVI & CIN + WVI & CINl + WVI & - & + \\
\hline 8 & CIN + WVI & $\mathrm{CIN}+\mathrm{WVI}$ & CIN2 + WVI & - & + \\
\hline 9 & Negative & $\mathrm{CIN}+\mathrm{WVI}$ & $\mathrm{CIN} 1 / 2+\mathrm{WVI}$ & - & - \\
\hline $10^{*}$ & Negative & CIN + WVI & CIN $1 / 2+W V I$ & - & + \\
\hline 11 & CIN & $\mathrm{CIN}+\mathrm{WVI}$ & CIN $3+$ WVI & - & + \\
\hline 12 & CIN + WVI & CIN & CIN3 + WVI & + & + \\
\hline 13 & CIN + WVI & CIN & CIN3 + WVI & - & $\begin{array}{l}\mathrm{T} \\
+\end{array}$ \\
\hline 14 & CIN + WVI & WVI & Negative & - & - \\
\hline 15 & CIN + WVI & $\mathrm{CIN}+\mathrm{WVI}$ & Negative & - & - \\
\hline 16 & Negative & WVI & Negative & - & + \\
\hline $17 *$ & Negative & $\mathrm{CIN}+\mathrm{WVI}$ & $\mathrm{CIN} 1 / 2$ & - & + \\
\hline 18 & CIN & CIN + WVI & CIN3 & - & + \\
\hline $19 *$ & Negative & CIN & CIN2 + WVI & - & - \\
\hline 20 & CIN & CIN & CIN2 + WVI & - & - \\
\hline 21 & CIN + WVI & CIN & CIN3 & - & - \\
\hline 22 & $\mathrm{CIN}+\mathrm{WVI}$ & CIN & CIN 3 & - & - \\
\hline
\end{tabular}

CIN = Cervical intraepithelial neoplasia (numbers represent grades).

WVI = Wart virus infection. 
TABLE II-Relation between wart virus infection and detection of human papillomavirus antigen and human papillomavirus type 6 DNA

\begin{tabular}{cccc}
\hline $\begin{array}{c}\text { Method of detection of } \\
\text { wart virus infection }\end{array}$ & $\begin{array}{c}\text { No } \\
\text { in group }\end{array}$ & $\begin{array}{c}\text { No with } \\
\text { papillomavirus } \\
\text { antigen }\end{array}$ & $\begin{array}{c}\text { No with } \\
\text { papillomavirus type 6 } \\
\text { DNA }\end{array}$ \\
\hline Cytology & 14 & 6 & 8 \\
Colposcopy & 16 & 5 & 11 \\
Histology & 15 & 6 & 10 \\
\hline
\end{tabular}

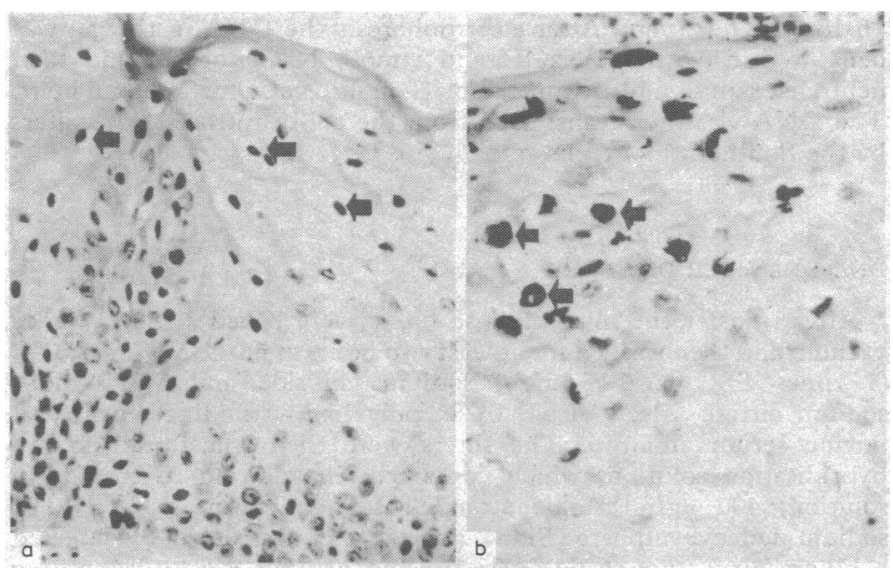

FIG 1 -Sections of a biopsy specimen (case 1). (a) Haematoxylin and eosin stained section showing typical features of a papillomavirus infection with koilocytotic cells with perinuclear vacuolisation (arrows). (b)-Immunoalkaline phosphatase staining with antiserum to the common antigen of human papillomaviruses. Red nuclei (darkly stained, arrows) contain papillomavirus antigen. Both $\times 150$ (original magnification).

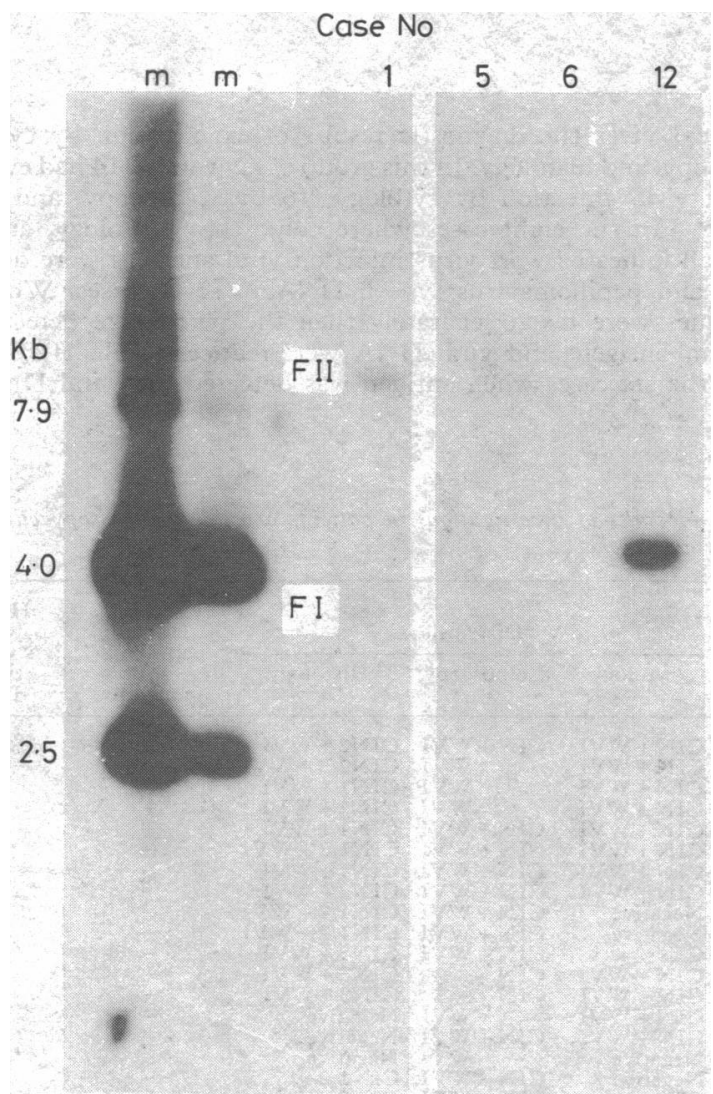

FIG 2-Blot hybridisation on nitrocellulose filters of total DNA from biopsy specimens from four patients. DNA digested with the restriction enzyme Eco Rl and hybridised with ${ }^{32} \mathrm{P}$-labelled pAT 153 cloned papillomavirus type 6 DNA. Lanes labelled " $m$ " contain digested pAT 153 and papillomavirus type 6 with sizes of resulting bands in kilobases indicated on left. found. Figure 1 gives examples of the histological findings and immunoalkaline staining of sections of the biopsy specimen from a patient, with fig 2 showing the equivalent DNA-DNA hybridisation pattern from the same patient indicating the presence of papillomavirus type 6 genomes.

\section{DNA-DNA HYBRIDISATION}

Normally in the virion the viral DNA is present as a supercoiled circular molecule (form I). On extraction, however, the DNA may become non-specifically nicked in one strand of the double helix to produce a circular molecule (form II) or nicked in both strands to become linear (form III). When the form I DNA is digested with a restriction enzyme that cuts the viral DNA at one site a linear, form $\frac{\mathscr{S}}{\vec{D}}$ III molecule is produced. Figures 2 and 3 show bands specific for $\stackrel{\mathbb{Q}}{\overparen{Q}}$ human papillomavirus type 6 in forms I and II after digestion of total biopsy DNA with Eco R1. This means that the viral DNA from these specimens is not digested with Eco R1, although DNA from $\vec{\circ}$ case 12 produced one band (fig 2) whose size is approximately half $\overrightarrow{\vec{\omega}}$ that of full length to papillomavirus type 6 DNA. This may mean $\vec{\omega}$ that the viral DNA in this specimen is digested twice by Eco R1 at positions that give two equal lengths of linear DNA. None of the 3 . other papillomavirus type 6 DNA detected was digested by Eco R1 i (figs $2,3,4$ ), but all those tested with Hind III were cut once producing $\infty$ a linear band (fig $4(a)$ and $(b)$ ). The above observations mean that the $\sigma$ viral DNA is in all cases present in a free form and not integrated into the host genome, as suggested by the presence of supercoiled $\mathrm{G}$ (form I) molecules. The viral DNA is present in amounts between $0 \cdot 1$ and 10 genome equivalents per cell.

Both viral antigen and viral DNA were detected in biopsy specimens 음 from patients with all grades of cervical intraepithelial neoplasia $\vec{v}$ (table III), indicating that the virus is present in the most severe cases, severe dysplasia and carcinoma in situ (grade 3 ).

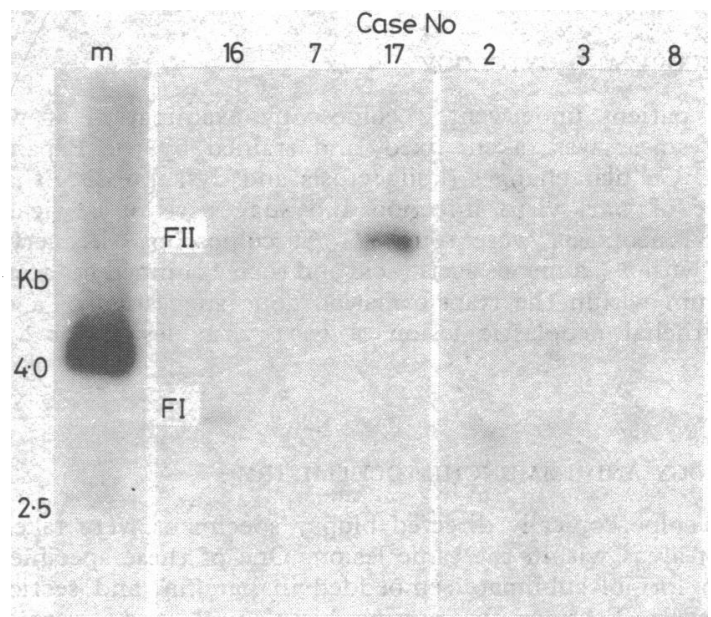

FIG 3-Blot hybridisation on nitrocellulose filters of total DNA from biopsy specimens from six patients. DNA digested with the restriction enzyme Eco R1 and hybridised with ${ }^{32} \mathrm{P}$-labelled pAT 153 cloned papillomavirus type 6. Lane " $\mathrm{m}$ " contains digested pAT 153 and papillomavirus type 6 with band sizes in kilobases indicated. DNA from all of these patients is present as form I and II as indicated.

TABLE III-Histological diagnosis for biopsy specimens containing viral antigen@ and viral DNA

\begin{tabular}{|c|c|c|}
\hline & $\begin{array}{c}\text { No with } \\
\text { papillomavirus } \\
\text { antigen }\end{array}$ & $\begin{array}{c}\text { No with } \\
\text { papillomavirus type } 6 \\
\text { DNA }\end{array}$ \\
\hline $\begin{array}{l}\text { Benign }(n=3) \\
\text { Neoplasia* types } 1 \text { and } 1 / 2(n=8) \\
\text { Neoplasia* types } 2 \text { and } 2 / 3(n=5) \\
\text { Neoplasia* type } 3(n=6)\end{array}$ & $\begin{array}{l}0 \\
3 \\
2 \\
1\end{array}$ & $\begin{array}{l}1 \\
5 \\
3 \\
4\end{array}$ \\
\hline
\end{tabular}



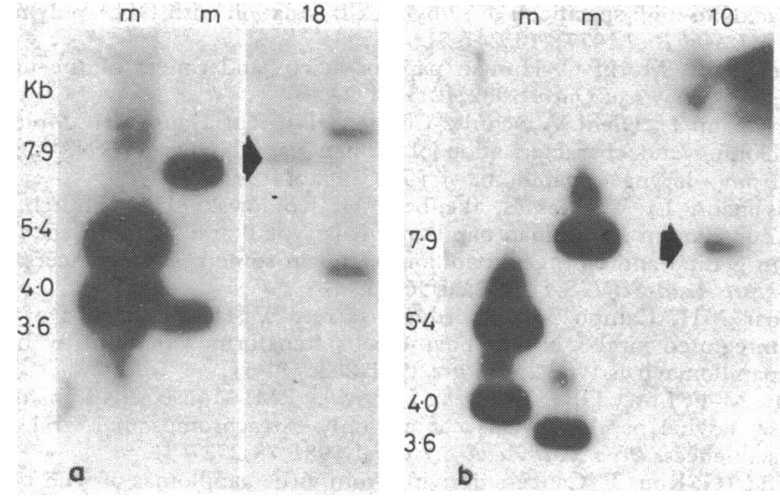

FIG 4 (a)-Blot hybridisations on nitrocellulose filters of total DNA from biopsy specimen (case 18). Left lane of 18 shows a form III band (arrow) after digestion of total DNA with Hind III while right lane shows form I and II bands after digestion with Eco R1.

FIG $4(b)$-Hybridisation pattern of total DNA from biopsy specimen (case 10) after digestion with restriction enzyme Hind III exhibiting a form III band (arrow).

\section{Discussion}

Of the 22 women with cervical epithelial abnormalities attending a colposcopy clinic six were found to have human papillomavirus antigens and 13 papillomavirus type 6 DNA. Of the six showing viral antigen, five also had detectable amounts of viral DNA. The discrepancy in the one biopsy specimen in which viral antigen but no viral DNA was found may be due to the fact that separate specimens were taken from the same lesion and different areas may contain varying amounts of viral DNA and antigen; alternatively, small undetectable levels of viral DNA may have been present in that particular specimen, from which only a small amount of DNA was extracted.

In one patient (case 16) colposcopy showed a small early wart virus infection at the squamous-columnar boundary but cytological and histological examinations were unable to confirm this diagnosis, although viral DNA was detected. The biopsy specimen studied by histology consisted primarily of endocervical epithelium, and this would explain the negative findings.

When examination by colposcopy, cytology, and histology indicated a cervical intraepithelial neoplasm with wart virus infection (eight cases) then DNA was detected in seven, and when the variables were taken separately DNA was detected in around $60 \%$ of cases (table 2). The results for the five patients referred from a clinic for sexually transmitted diseases did not distort the figures, as viral DNA was found in the biopsy specimens of nine of the 17 women referred from general practitioners and family planning clinics, a figure close to $59 \%$ in the group as a whole.

The viral DNA isolated from all cases except one (case 12) were undigested by the restriction enzyme Eco R1 but were cut once to produce a linear molecule by Hind III and Bam HI (not shown). Also, in one case digestion with the enzyme Hpa II produced at least six bands (not shown). The human papillomavirus type 6 radiolabelled probe used did not cross hydbridise at the stringent conditions of the experiments with human papillomavirus types 1a, 2, or 4 (plantar and common hand warts and gifts of Dr P M Howley, National Cancer Institute, USA). The results with these few enzymes suggest that most viral DNAs detected in this study are of a subtype of human papillomavirus type 6 different to the cloned type 6 used as probe. ${ }^{16}$ One of us (DJ McC) has found this subtype most frequently in exophytic cervical and vulvar warts from patients in the London area.

Although in this study wart virus infection was associated with cervical intraepithelial neoplasia in all cases by at least one of the techniques used, papillomavirus type 6 DNA was detected in only $59 \%$ and viral antigen in $27 \%$ of cases. Does this mean an overestimation of wart virus infection by other techniques in this study and by others, ${ }^{72}$ or is the method of detection not sensitive enough to pick up the presence of viral DNA in all cases? Certainly the biopsy specimens are small and total DNA extracted only allows a few tests to be carried out. Also, using two specimens, one for histology and immunohistochemistry and the other for DNA extraction, may lead to anomalous results because of the variable amounts of virus in each area. Even in exophytic cervical warts and vulvar warts there is a variable amount of viral antigen in the cells. ${ }^{11} 12$ Another human papillomavirus type 11, has recently been found in laryngeal warts ${ }^{23}$ and in a small percentage of genital warts and in five cases of atypical condylomata of the cervix. ${ }^{24}$ This virus, which has $25 \%$ homology with type 6 and should therefore not cross hybridise in the stringent conditions used in this study, may explain the cases of cervical intraepithelial neoplasia in which no human papillomavirus type 6 was found.

What does the prevalency of the viral DNA mean in terms of the aetiology of cervical intraepithelial neoplasia and progression from grade 1 to grade 3 and perhaps to microinvasive carcinoma? Papillomavirus type 6 DNA was found equally often in this study at all stages of cervical intraepithelial neoplasia (table III) and appears to be present as free DNA and not integrated into the host genomes, a finding also found experimentally in cells transformed by bovine papillomaviruses. ${ }^{25}{ }^{26}$ Animal papillomaviruses produce skin carcinomas in rabbits $^{27}$ and bladder and gastrointestinal carcinomas in cows in conjunction with an environmental carcinogen. ${ }^{28}$ In women condylomata acuminata has been shown to convert to a carcinoma of the vulva ${ }^{29}$ and in another study carcinomas of the vulva were shown to have histological features consistent with papillomavirus infection, ${ }^{30}$ while human papillomavirus type 11 has been found in three carcinomas (two in situ and one invasive) out of 24 malignant cervical tumours tested. ${ }^{24}$ DNA from human papillomavirus types 5 and 8 have been found in skin squamous cell carcinomas in patients with the rare autosomal recessive disease epidermodysplasia verruciformis ${ }^{14}{ }^{31}$ and laryngeal warts known to be caused by human papillomavirus type $6^{32}$ have on treatment by radiotherapy become malignant. ${ }^{33}{ }^{34}$ Zur Hausen has suggested that human papillomavirus infections of the cervix may make the epithelial cells susceptible to malignant change by other factors such as herpes simplex infection or other insults on the cervical epithelium, ${ }^{35}$ as is seen with oesophageal and intestinal carcinomas in cattle. ${ }^{28}$ Epidemiological studies show an association between carcinoma of the cervix and sexual behaviour, especially with an increased number of partners and early age of first intercourse, and a transmissible agent is thought responsible. ${ }^{36}{ }^{37}$ Whatever part, if any, human papillomavirus infection plays in producing carcinoma of the cervix, our results show, for the first time, that human papillomavirus type 6 DNA is present in over half of the histologically proved cases with cervical intraepithelial neoplastic lesions. It could, however, be argued that human papillomavirus type 6 DNA may be present in a high percentage of individuals with a normal cervix. This is to be tested in a large controlled study on the prevalence of human papillomavirus type 6 infection in women.

Part of this work was supported by an MRC grant (No G8296557CA) to DJ McC and a CRC grant (Path 4) to DVC, and $\mathrm{PGW}$ received a Florence and William Blair Bell fellowship from the Royal College of Obstetricians and Gynaecologists.

\section{References}

${ }^{1}$ Marsh MR. Papilloma of the cervix. Am $\mathcal{f}$ Obstet Gynecol 1952;64: 281-91.

${ }^{2}$ Raftery A, Payne WS. Condyloma acuminata of the cervix. Obstet Gynecol $1954 ; 4: 581-4$

${ }^{3}$ Oriel JD. Natural history of genital warts. Br $\mathcal{F}$ Vener Dis 1971;47:1-13. 
4 Meisels A, Fortin R. Condylomatous lesions of the cervix and vagina. 1. Cytologic patterns. Acta Cytol (Baltimore) 1976;20:505-9.

5 Purola A, Savia E. Cytology of gynecologic condyloma acuminatum. Acta Cytol (Baltimore) 1977;21:26-31.

${ }^{6}$ Meisels A, Fortin R, Roy M. Condylomatous lesions of the cervix and vagina. II. Cytologic, colposcopic and histopathologic criteria. Acta Cytol (Baltimore) $197^{\urcorner} ; 21: 379-89$.

${ }^{2}$ Reid R, Stanhope R, Herschman BR, Booth E, Phibbs GD, Smith JP. Genital warts and cervical cancer. I. Evidence of an association between subclinical papillomavirus infection and cervical malignancy. Cancer $1982 ; 50: 377-87$

${ }^{8}$ Reid R, Laverty CR, Coppleson M, Isarangkul W, Hills E. Noncondylomatous cervical wart virus infection. Obstet Gynecol 1980;55:476-85.

${ }^{9}$ Walker PG, Singer A, Dyson J, Shah KV, Wilters J, Coleman DV. Colposcopy in the diagnosis of papillomavirus infection of the uterine cervix (in press)

10 Ferenczy A, Braun L, Shah KV. Human papillomavirus (HPV) in condylomatous lesions of cervix. Am f Surg Pathol 1981;5:661-70.

11 Kurman RJ, Shah KH, Lancaster WD, Jenson AB. Immunoperoxidase localization of papillomavirus antigens in cervical dysplasia and vulvar condylomas. Am $\mathcal{F}$ Obstet Gynecol $1981 ; 140: 931-5$.

12 Woodruff JD, Braun L, Cavalieri R, Gupta P, Pass F, Shah KV. Immunological identification of papillomavirus antigen in paraffinprocessed condyloma tissues from the female genital tract. Obstet Gynecol 1980;56:727-32.

13 Green M, Brackmann KJ, Sanders PR, et al. Isolation of a human papillomavirus from a patient with epidermodysplasia verruciformis: presence of related viral DNA genomes in human urogenital tumors. Proc Natl Acad Sci USA 1982;79:4437-41.

14 Ostrow RS, Bender M, Niimura M, et al. Human papillomavirus DNA in cutaneous primary and metastasized squamous cell carcinomas from patients with epidermodysplasia verruciformis. Proc Natl Acad Sci USA $1982 ; 79: 1634-8$.

15 Chesters PM, Heritage J, McCance DJ. Persistence of DNA sequences of BK virus and $\mathrm{JC}$ virus in normal human tissues and in diseased tissues. F Infect Dis 1983;147:676-84.

16 Gissmann L, de Villiers EM, Zur Hausen H. Analysis of human genital warts (condylomata acuminata) and other genital tumors for human papillomavirus type 6 DNA. Int $\mathcal{F}$ Cancer 1982;29:143-6.

${ }^{17}$ Buckley $\mathrm{CH}$, Butler EB, Fox $\mathrm{H}$. Cervical intraepithelial neoplasia. $\mathcal{f}$ Clin Pathol 1982;35:1-13.

${ }^{18}$ Heritage J, Chesters PM, McCance DJ. The persistence of papovavirus BK DNA sequences in normal human renal tissue. $f$ Med Virol 1981; 8:143-50.

19 Jenson AB, Rosenthal JR, Olson C, Pass F, Lancaster WD, Shah KV. Immunological relatedness of papillomaviruses from different species. FNCI 1980;64:495-500.

20 Southern EM. Detection of specific sequences among DNA fragments separated by gel electrophoresis. F Mol Biol 1975;98:503-17.

${ }^{21}$ Rigby PWS, Dieckman M, Rhodes C, Berg P. Labelling deoxyribonucleic acids to high specific in vitro by nick translation with DNA polymerase I. 7 Mol Biol 1977;113:247-51.

${ }^{2}$ Meisels A, Morin C. Human papillomavirus and cancer of the uterine cervix. Gynecol Oncol 1982;12:5111-23.

23 Gissmann L, Diehl V, Schultz-Coulton H-J, Zur Hausen H. Molecular $\widehat{O}$ cloning and characterisation of human papillomavirus DNA derived $\overline{\bar{z}}$ from a laryngeal papilloma. $\mathcal{F}$ Virol $1982 ; 44: 393-400$.

24 Gissmann L, Wolnick L, Ikenberg H, Koldowsky U, Schnurch HG, Zur Hausen $H$. Human papillomavirus type 6 and 11 DNA sequences $\infty$ in genital and laryngeal papillomas and in some cervical cancers. Proc Natl Acad Sci USA 1983;80:560-3.

${ }^{25}$ Moar MH, Campo MS, Laird H, Jarrett WFH. Persistence of nonintegrated viral DNA in bovine cells transformed in vitro by bovine $\stackrel{5}{\rightarrow}$ papillomavirus type 2 . Nature $1981 ; 293: 749-51$.

26 Law M-F, Lowy DR, Dvoretzky I, Howley PM. Mouse cells transformed by bovine papillomavirus contain only extrachromosomal viral DNA sequences. Proc Natl Acad Sci USA 1981 ;78:2727-31.

27 Kidd JG, Rous P. Cancers deriving from virus papillomas of wild rabbits under natural conditions. $\mathcal{F} \operatorname{Exp}$ Med 1940;71:469-93.

2* Jarrett WF, McNeill P, Grimshaw W, Selman I, McIntyre W. High के incidence area of cattle cancer with a possible interaction between an $\overrightarrow{0}$ environmental carcinogen and a papilloma virus. Nature 1978;274: ? 215-7.

29 Shafeek MA, Osman MI, Hussein MA. Carcinoma of the vulva arising $\vec{\omega}$

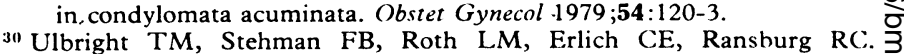
Bowenoid dysplasia of the vulva. Cancer $1982 ; 50: 2910-9$.

31 Orth G, Jablonska S, Favre M, Croissant O, Jarzabek-Chorzelska M, Rzesa G. Characterisation of two types of human papillomaviruses in. lesions of epidermodysplasia verruciformis. Proc Natl Acad Sci USA $1978 ; 75: 1537-41$.

${ }^{32}$ Mounts P, Shah KV, Kashima H. Viral etiology of juvenile-and adult- or onset squamous papilloma of the larynx. Proc Natl Acad Sci USA $1982 ; 79: 5425-9$.

${ }^{33}$ Kleinsasser $O$. Uber die gut-und bösartigen Formen der Kehlkopf- 음 papilloma und daren histologisches und Klinisches Bild. Archiv fur $\rightarrow$ Ohren-, Nasen-, und Kehlkopfheilkunde 1958;174:44-69.

${ }^{34}$ Maier I. Maligne Entartung bestrahlter juveniler Larynxpapollome. $\mathcal{C}$ Zeitschrift fur Laryngologie Rhinologie, Otologie und Ihre Grenzgebicto $\frac{\mathbb{D}}{0}$ $1968 ; 47: 862-9$.

${ }^{35}$ Zur Hausen H. Human genital cancer: synergism between two virus infections or synergism between a virus infection and initiating events. Lancet 1982 ;ii: $1370-2$.

${ }^{36}$ Rotkin ID. A comparison review of key epidemiological studies in cervical $\vec{C}$ cancer related to current searches for transmissible agents. Cancer Res $\infty$ $1973 ; 33: 1353-67$.

37 Kessler II. Human cervical cancer as a venereal disease. Cancer Res $1976 ; 36: 783-91$.

(Accepted 10 fune 1983)
ONE HUNDRED YEARS AGO The manufacture and consumption of potted and minced meat have greatly increased during the last few years, and competition has become so keen, that the more unscrupulous manufacturers, in their anxiety to undersell, do not hesitate to employ meat which is of such an unsound condition, as to be quite unsaleable if presented to the public in any other form. Horse flesh, on account of its cheapness, is the favourite article with the sausage manufacturer, and large quantities are being used every week for the manufacture of German and breakfast sausages. In London, the trade is almost entirely carried on in the East-end, the horse-flesh being procured either from the country, or from unlicensed slaughterers. The inspector to the Poplar Board of Works, Mr Raymond, succeeded in obtaining two convictions against users of this substance; but although both were very bad cases, the magistrate contented himself with imposing a fine of $£ 20$. In the interests of the public we are, therefore, pleased to see that at Aston, near Birmingham, William Henry White was convicted and sentenced, on two distinct summonses, to six months' imprisonment, for having in his possession a quantity of unwholesome rinds of bacon and pork; 352 pieces of partially decomposed horse-flesh were also found on his premises, doubtless waiting to be converted either into sausages, or some cheap form of potted meat. The magistrates stated that this was the highest. penalty which they could inflict. A few more sentences equally severe would go far towards putting down a most nefarious trade. It is contended by some that horseflesh is almost equal as a food to beef $\mathcal{O}$ or mutton; but those who hold these views should remember that the 3 source from which it is obtained for the manufacture of potted beefo and sausages is such as to cause it to be viewed with great suspicion and distrust. Certainly the use as food of the produce of a knacker's $\widetilde{N}$ yard, where beasts in all stages of disease and starvation are slaughtered, $\rightarrow$ cannot be too strongly condemned, and it is possible that among our poorest population, much disease and sickness is caused by partaking of unsound meat, in a form where its objectionable characters are masked by the flavouring matters added during preparation, but in $\omega$ which, nevertheless, exist the germs of putrefaction, waiting only for a favourable soil to increase and multiply, and lay the foundationco of disorders which seriously tax our medical resources. (British Medical fournal $1883 ; \mathrm{i}: 265$.) 